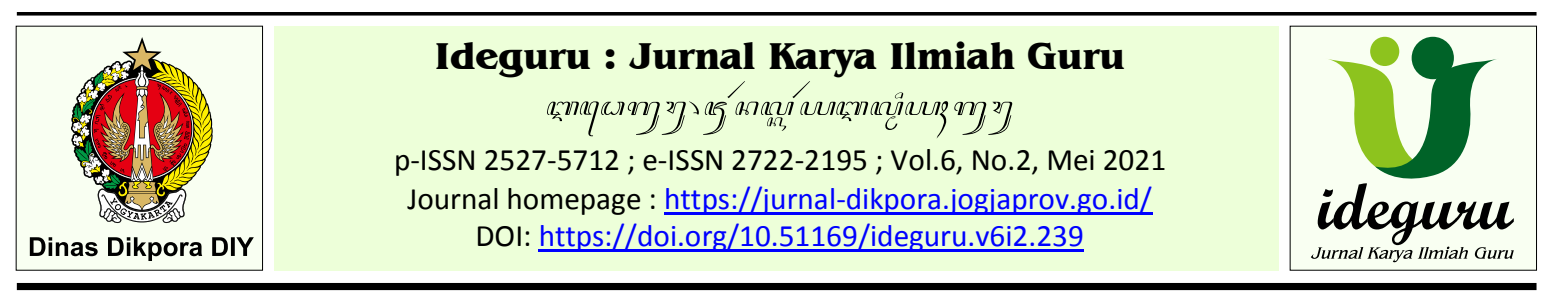

Best Practice - Naskah dikirim: 13/02/2021 - Selesai revisi: 26/03/2021 - Disetujui: 28/03/2021 - Diterbitkan: 01/05/2021

\title{
Penggunaan Model Pembelajaran Project Based Learning melalui Google Classroom dalam Pembelajaran Menulis Teks Prosedur
}

\author{
Dariyo Soleh \\ SMP Negeri 2 Mirit, Kebumen, Jawa Tengah \\ Sh00leh.7770@gmail.com
}

\begin{abstract}
Abstrak: Kegiatan Pembelajaran Jarak Jauh (PJJ) merupakan tantangan besar bagi guru karena belum pernah mengalami sebelumnya. Model Pembelajaran Project Based Learning Melalui Google Classroom merupakan salah satu alternatif yang bisa diterapkan oleh guru pada kegiatan Pembelajaran Jarak Jauh (PJJ). Tujuan penelitian ini adalah untuk mengetahui apakah Model Pembelajaran Project Based Learning melalui Google Classroom dapat diterapkan dalam kegiatan pembelajaran di kelas IXF SMP Negeri 2 Mirit Kebumen. Sintaks Pembelajaran Project Based Learning yaitu pertama, pertanyaan mendasar, kedua, mendesain perencanaan produk, ketiga, menyusun jadwal pembuatan, keempat, memonitor keaktifan dan perkembangan proyek, kelima, menguji hasil, dan keenam, evaluasi pengalaman belajar. Hasilnya menunjukkan bahwa secara umum siswa dapat membuat teks prosedur dengan benar. Perolehan nilai siswa dapat dideskripsikan bahwa nilai rata-rata sebesar 81, nilai tertinggi 94 dan nilai terendah 72 . Ada satu siswa yang mendapatkan nilai 94, tiga siswa mendapat nilai 88 , tujuh siswa mendapatkan nilai 86 , dua siswa mendapatkan nilai 84 , enam siswa mendapatkan nilai 82 , tiga siswa mendapatkan nilai 78 , dua siswa mendapatkan nilai 76 , dan ada tujuh siswa yang mendapat nilai 72 .
\end{abstract}

Kata kunci: project based learning, google classroom, teks prosedur

\section{The Use of Project Based Learning Models through Google Classroom in Learning Writing Procedure Texts}

\begin{abstract}
Distance Learning Activities (DLA) is a big challenge for teachers because they have never experienced it before. Project Based Learning Model Through Google Classroom is one of the alternatives that can be applied by teachers to Distance Learning Activities (DLA). The purpose of this study is to find out if the Project Based Learning Model through Google Classroom can be applied in learning activities in Grade IXF of SMP Negeri 2 Mirit Kebumen. The Syntax of Project Based Learning is first, fundamental questions, second, designing product planning, third, drawing up a manufacturing schedule, fourth, monitoring the activeness and development of the project, fifth, testing the results, and sixth, evaluation of the learning experience. The results showed that in general, students can make procedure text correctly. The outcome of students learning can be described that the average score is 81, the top score is 94 and the lowest score is 72 . There was one student who got 94, three students got 88, seven students got 86, two students got 84, six students got 82, three students got 78, two students got 76, and there were seven students who got 72 .
\end{abstract}

Keywords: project based learning, google classroom, procedure text

\section{Pendahuluan}

Siswa Kelas IXF SMP Negeri 2 Mirit merupakan siswa yang partisipasi presensi daringnya paling rendah dibandingkan dengan 5 kelas lainnya. Demikian juga antusiasme mereka untuk mengikuti kegiatan Pembelajaran Jarak Jauh (PJJ) juga kurang. Hal ini dapat dilihat dari kurang aktifnya mereka dalam berkomunikasi atau menulis di chat grup WA atau di chat forum di Google Classroom. Kurang aktif menulis ini yang akan penulis coba untuk mencarikan solusinya agar mereka dapat meningkatkan belajar bahasa Inggris khususnya pada materi menulis teks prosedur.

Pembelajaran teks prosedur di kelas IX cukup kompleks lingkup permasalahanya. Dinas Pendidikan Kabupaten Kebumen (2020), menyebutkan bahwa pembelajaran teks prosedur di Masa Pandemi dinyatakan pada KD 4.1 Menangkap makna secara kontekstual terkait fungsisosial, struktur teks, dan unsur kebahasaan teks prosedur lisan dan tulis, sangat pendek dan 
sederhana, dalam bentuk resep dan manual. Menurut KD tersebut ada dua sub materi yang akan dipelajari oleh siswa yaitu teks prosedur tentang resep dan teks prosedur tentang manual. Teks prosedur tentang resep berkaitan dengan bagaimana cara membuat suatu makanan atau minuman. Sedangkan teks prosedur tentang manual berkaitan dengan bagaimana cara mengoperasikan sesuatu.

Adapun Indikator Essensialnya yaitu; pertama, Menerapkan fungsi sosial, struktur teks, dan unsur kebahasaan dalam teks prosedur lisan dan tulis; kedua, menjelaskan dan menerapkan beberapa teks prosedur (resep makanan dan minuman) baik secara lisan maupun tulis.

Mengingat materi teks prosedur yang cukup kompleks, maka perlu merumuskan kegiatan pembelajaran yang kontekstual dan relevan.

Dengan melihat situasi dan kondisi yang masih dalam masa Pencegahan Pandemi Covid 19, maka model pembelajaran yang dipandang cocok untuk kelas IXF adalah model pembelajaran Project Based Learning. Model Pembelajaran ini sangat sesuai diterapkan dalam kegiatan pembelajaran jarak jauh.

Pada era sekarang, guru diberi keleluasaan untuk memilih aplikasi online mana yang dipandang cocok sehingga guru dan siswa bisa berinteraksi dan berkomunikasi di kelas maya (Marharjono, 2020).

Maka dari itu, kegiatan pembelajaran ini akan menggunakan Google Classroom. Aplikasi ini dipandang sesuai untuk membelajarkan siswa menulis teks prosedur dengan menggunakan model pembelajaran Project Based Learning. Kegiatan pembelajaran ini dirancang untuk bisa diterapkan pada kegiatan Pembelajaran Jarak Jauh (PJJ) atau Belajar di Rumah (BDR).

Berdasarkan uraian di atas, rumusan masalah dalam penulisan best practice ini adalah; 1) apakah kompetensi menulis teks prosedur dapat dicapai melalui Model Pembelajaran Project Based Learning menggunakan Google Classroom. 2) bagaimanakah sintaks Model Pembelajaran Project Bsed Learning.

Adapun tujuan dalam penulisan ini adalah; pertama, siswa dapat menulis teks prosedur dengan benar. kedua siswa mampu menguasai literasi digital dengan menggunakan media online Google Classroom.

Penelitian ini diharapkan memberikan manfaat, baik secara teoretis maupun praktis. Manfaat teoretis yaitu melaui penelitian ini diharapkan dapat memberikan sumbangan pemikiran tentang strategi melaksanakan pembelajaran menulis teks prosedur di masa pandemi. Sedangkan manfaat praktis yaitu; bagi siswa, dapat membantu belajar menulis teks prosedur di kelas maya menggunakan Google Classroom, dan bagi guru, dapat memberi wacana baru bagi guru tentang kemudahan melaksanakan pembelajaran menggunakan Google Classroom.

\section{Tinjauan Pustaka}

Model Pembelajaran Project Based Learning adalah model pembelajaran yang bisa melatih siswa untuk lebih aktif dan mandiri dalam kegiatan pembelajaran. Pada masa Pandemi Covid 19 melatih siswa untuk lebih aktif sangat diperlukan supaya siswa tidak merasa jenuh belajar di rumah selama berbulan-bulan. Dalam kegiatan pembelajaran jarak jauh desain pembelajaran perlu difokuskan ke arah kemandirian siswa dalam penyelesaian tugas proyek. Pemberian tugas proyek kepada siswa bisa membangkitkan keterampilan berfikir siswa untuk menentukan proyek membuat apa yang akan dilaksanakan, mulai kapan akan dilaksanakan dan perlu berapa lama penyelesaiannya. Dari tahapan-tahapan penyelesaian tugas proyek bisa menumbuhkan sikap positif pada siswa berupa sikap disiplin terhadap jadwal yang telah dibuat dan sikap tekun dalam mengerjakan tugas proyek. (Yuliana, 2020)

Secara lebih lengkap Kementerian Pendidikan dan Kebudayaan (2014), menjelaskan bahwa Pembelajaran Berbasis proyek merupakan pembelajaran yang lengkap, berkesinambungan dan bisa membuat siswa aktif bergerak mencari informasi untuk melengkapi tugas proyek yang dibuat. Aktivitas-aktivitas siswa untuk mengasilkan produk dengan menerapkan keterampilan meneliti, menganalisis, membuat, dan mempresentasikan merupakan suatu hal yang ditekankan dalam kegiatan pembelajaran Project Based Learning ini. Hasil siswa mengerjakan tugas proyek bisa berbentuk desain, skema, karya tulis, karya seni, karya teknologi/prakarya dan lain-lain. Pada situasi normal, pendekatan ini memperkenalkan siswa untuk menghasilkan produk nyata baik dilakukan secara mandiri maupun berkelompok. Sedangkan pada masa Pandemi Covid 19 siswa diarahkan untuk menghasilkan produknya secara mandiri.

Selanjutnya Kementerian Pendidikan dan Kebudayaan (2014), menjelaskan bahwa tujuan pembelajaran berbasis proyek adalah sebagai berikut: 1) Memperoleh pengetahuan dan keterampilan baru dalam pembelajaran, 2) Meningkatkan kemampuan siswa dalam menyelesaikan proyek, 3) Membuat siswa lebih 
aktif dalam menyelesaikan proyek yang kompleks.

\section{Google Classroom}

Google adalah perusahaan multinasional Amerika Serikat yang bergerak di bidang layanan jasa dan produk internet. Di bidang pendidikan Google meluncurkan produk Google Classroom yang bertujuan mengembangkan kegiatan pembelajaran tanpa kertas yang meliputi penyederhanaan pembuatan, pendistribusian dan pengumpulan tugas. (Rosidah, 2020)

Nurrohmah (2019), menambahkan bahwa Google Classroom terhubung dengan Google Drive dan Google Docs yang memungkinkan guru dan siswa untuk mendapatkan akses yang sangat cepat. Dengan layanan ini guru bisa membuat dokumen dengan mudah. Demikian juga siswa pun juga bisa berkolaborasi dalam mengerjakan tugas proyek yang diberikan guru. Hal ini tentunya sangat bermanfaat bagi guru dan siswa.

Penyederhanaan dalam proses berbagi file antara guru dan siswa merupakan tujuan utama pembuatan Google Classroom. Selain itu, Google Classroom juga terkoneksi dengan Google Drive untuk pembuatan dan pendistribusian penugasan, Google Docs, Sheets dan Slides untuk fasilitas menulis naskah dan sejenisnya, Gmail digunakan untuk komunikasi dan Google Calendar untuk pembuatan jadwal.

\section{Pembahasan}

Kegiatan pembelajaran menulis teks prosedur dilaksanakan pada tanggal 1-15 Oktober, 2020. Adapun subyeknya adalah siswa kelas IX F SMP Negeri 2 Mirit, Kebumen, Jawa Tengah.

Proses kegiatan pembelajarannya dilaksanakan dengan model Pembelajaran Jarak Jauh (PJJ) mengingat anjuran pemerintah yang menetapkan bahwa kegiatan pembelajaran di jenjang Pendidikan Dasar dan Menengah Tahun Pelajaran 2020/2021 dilaksanakan secara daring. (Kementerian Pendidikan dan Kebudayaan, 2020).

Pembelajaran Jarak Jauh atau belajar dari rumah dapat berhasil dengan baik dan bermakna apabila didukung oleh empat komponen yaitu; 1) kemampuan guru memanfaatkan teknologi, 2) pembelajaran terencana dan efektif, 3) menyatukan persepsi dan konsentrasi siswa, 4) penguatan karakter siswa. (Harususilo, 2020).

Penguatan pendidikan karakter yang dikembangkan dalam materi pelajaran ini adalah penumbuhan sifat disiplin, percaya diri dan bertanggung jawab pada semua siswa. Dengan ketiga sifat tersebut, diharapkan bisa menjadi daya ungkit siswa dalam menyelesaikan tugas proyek sesuai dengan yang direncanakan.

\section{Perencanaan Best Practice}

Tahapan pembelajaran menulis teks prosedur diawali dengan guru membuat Rencana Pelaksanaan Pembelajaran (RPP) model satu lembar yang di dalamnya memuat empat komponen yaitu; tujuan pembelajaran, media, alat/bahan pembelajaran dan sumber belajar, langkah-langkah pembelajaran, dan penilaian hasil belajar.

Tujuan dari pembelajaran ini adalah siswa dapat; menulis judul dengan benar, membuat rencana menulis teks prosedur, menulis bahanbahan yang diperlukan, menulis langkah-langkah yang harus dilaksanakan, dan menyajikan teks prosedur dengan benar dan menarik.

Dalam masa Pandemi Covid-19 guru berusaha menyesuaikan kondisi dalam penyajian dan pengumpulan tugas proyek siswa dengan tetap memperhatikan protokol kesehatan dan siswa tetap berada di rumah.

Pada awal pembelajaran, guru memulai dengan salam, doa dan mengecek kehadiran, guru menyampaikan materi tentang teks prosedur yang meliputi definisi teks prosedur, fungsi sosial, struktur teks dan unsur kebahasaan.

Menurut Anderson (2003), teks prosedur didefinisikan secara jelas sebagai berikut:

"Prosedur adalah suatu jenis teks yang memberi (penjelasan) kepada kita (tentang) instruksi untuk mengerjakan sesuatu. Tujuan dari teks prosedur adalah untuk menjelaskan bagaimana sesuatu itu dapat dilakukan ".

Zaida (2009) menambahkan, teks prosedur adalah teks yang menjelaskan tentang bagaimana cara untuk melakukan atau membuat sesuatu.

Adapun fungsi sosial dari teks prosedur adalah mendeskripsikan bagaimana sesuatu itu diselesaikan melalui serangkaian tindakan. Atau dengan kata lain, fungsi sosial dari teks prosedur adalah menjelaskan bagaimana cara membuat sesuatu atau mengoperasikan sesuatu. (Wardiman, 2008).

Susilohadi (2008), menjelaskan bahwa struktur teks prosedur terdiri dari 3 bagian yaitu; judul, daftar bahan yang diperlukan dan rangkaian tahapan yang harus dilakukan. Pada bagian judul berisi pengenalan tentang tujuan dari penulisan teks prosedur. Misalnya; Bagaimana Cara Membuat Agar-Agar. Sedangkan pada bagian daftar bahan yang diperlukan berisi bahan bahan yang diperlukan pada proses pembuatannya. Dan pada rangkaian tahapan berisi penjelasan tentang tahapan-tahapan yang harus dilakukan secara berurutan. 
Media yang digunakan dalam kegiatan pembelajaran ini adalah Google Meet, What's App Grup Kelas, dan Google Classroom. Google Meet digunakan pada kegiatan pendahuluan yaitu untuk menyapa siswa dengan salam, mengajak siswa berdoa untuk memulai pelajaran, menyampaikan tujuan pembelajaran, dan menyampaikan materi pelajaran. What's App Grup Kelas digunakan untuk memberi informasi kepada siswa tentang waktu jam berapa kegiatan pembelajaran akan dilaksanakan dan digunakan untuk mengirim link Google Meet. Selain itu What's App Grup Kelas juga digunakan untuk komunikasi antara siswa dan guru apabila ada siswa yang ingin bertanya atau meminta penjelasan. Adapun Google Classroom sebagai media utama dalam kegiatan pembelajaran ini berfungsi untuk menyampaikan uraian materi di fitur materi, menyampaikan pemberian tugas proyek siswa di fitur tugas dan untuk mengirim link kehadiran siswa.

\section{Pelaksanaan Pembelajaran}

Dalam melaksanakan pembelajaran guru berpijak pada Kurikulum Tingkat Satuan Pendidikan (KTSP) Penyederhanaan Pencapaian Indikator
Kompetensi. Pada aturan tersebut dinyatakan bahwa pembelajaran materi teks prosedur di Masa Pandemi Covid 19, alokasi waktu nya 8 pertemuan. (Dinas Pendidikan, 2020).

Sintaks model pembelajaran Project Based Learning ada enam tahap yaitu; 1) penentuan pertanyaan mendasar (start with essential questions), 2) mendesain pelaksanaan proyek (design a plan for the project), 3) menyusun jadwal (create a schedule), 4) memonitor siswa dan kemajuan proyek (monitor the students and the progress of the project), 5) menguji hasil (asses the outcome), dan 6) mengevaluasi pengalaman (evaluate the experience). (Suryaman, 2020).

Dalam pelaksanaan pembelajaran, sintaks satu sampai tiga dibelajarkan pada pertemuan pertama. Sedangkan sintaks empat sampai enam dibelajarkan pada pertemuan selanjutnya.

Sebelum melaksanakan kegiatan pembelajaran, guru menyusun Rencana Pelaksanaan Pembelajaran (RPP) mengacu pada Rencana Pelaksanaan Pembelajaran (RPP) satu lembar dan menggunakan enam sintaks (Mendikbud, 2019). Rencana Pelaksanaan Pembelajaran (RPP) diuraikan pada tabel 1 dan tabel 2 berikut.

Tabel 1. Desain RPP Menulis Teks Prosedur Pertemuan Kesatu.

\begin{tabular}{|c|c|}
\hline \multicolumn{2}{|r|}{ Kegiatan Pendahuluan (15 menit) } \\
\hline \multicolumn{2}{|c|}{$\begin{array}{l}\text { Membuka kegiatan pembelajaran dengan salam, berdoa, dan memeriksa kehadiran siswa sebaga } \\
\text { bentuk sikap disiplin. }\end{array}$} \\
\hline \multicolumn{2}{|c|}{$\begin{array}{l}\text { Mangaitkan materi pembelajaran yang akan dilakukan dengan pengalamana siswa dengan mater } \\
\text { sebelumnya serta mengajukan pertanyaan untuk mengingat dan menghubungkan dengan mater } \\
\text { selanjutnya. }\end{array}$} \\
\hline \multirow{2}{*}{\multicolumn{2}{|c|}{$\begin{array}{l}\text { Menyampaikan motivasi tentang tujuan dan manfaat dengan mempelajari materi : Teks Prosedur } \\
\text { Menjelaskan hal-hal yang akan dipelajari, kompetensi yang akan dicapai, serta metode belaja } \\
\text { yang akan ditempuh. }\end{array}$}} \\
\hline & \\
\hline Sintaks & Kegiatan Inti (50 menit) \\
\hline $\begin{array}{l}\text { 1. Pertanyaan } \\
\text { Mendasar }\end{array}$ & $\begin{array}{l}\text { Guru memberi kesempatan kepada siswa untuk bertanya terkait dengan apa } \\
\text { itu teks prosedur, apa fungsi sosialnya, apa struktur teksnya dan apa unsur } \\
\text { kebahasaannya. }\end{array}$ \\
\hline $\begin{array}{l}\text { 2. Mendesain } \\
\text { perencanaan } \\
\text { produk }\end{array}$ & $\begin{array}{l}\text { Guru membimbing siswa untuk berfikir rencana desain produk teks } \\
\text { prosedur akan dibuat seperti apa, akan menulis tentang cara membuat } \\
\text { makanan jenisnya apa, bingkainya bagaimana dan sebagainya. }\end{array}$ \\
\hline $\begin{array}{l}\text { 3. Menyusun } \\
\text { jadwal }\end{array}$ & $\begin{array}{l}\text { Siswa membuat jadwal menulis teks prosedur selama satu minggu ke depan } \\
\text { yang meliputi : Goal, Ingredients dan Steps di lembar kertas yang menarik. }\end{array}$ \\
\hline \multicolumn{2}{|r|}{ Kegiatan Penutup (15 menit) } \\
\hline \multicolumn{2}{|c|}{$\begin{array}{l}\text { Siswa membuat rangkuman/simpulan pelajaran tentang point-point penting yang muncul dalam } \\
\text { kegiatan pembelajaran yang baru dilakukan. }\end{array}$} \\
\hline Guru mengingatkan & $\begin{array}{l}\text { embali kepada siswa bahwa pada pertemuan yang akan datang siswa sudah } \\
\text { edur dengan benar. }\end{array}$ \\
\hline
\end{tabular}


Tabel 2. Desain RPP Menulis Teks Prosedur Pertemuan Kedua.

\begin{tabular}{|c|c|}
\hline \multicolumn{2}{|r|}{ Kegiatan Pendahuluan (15 menit) } \\
\hline \multicolumn{2}{|c|}{$\begin{array}{l}\text { Membuka kegiatan pembelajaran dengan salam, berdoa, dan memeriksa kehadiran siswa sebagai } \\
\text { bentuk sikap disiplin. }\end{array}$} \\
\hline \multicolumn{2}{|c|}{$\begin{array}{l}\text { Mangaitkan materi pembelajaran yang akan dilakukan dengan pengalamana siswa dengan materi } \\
\text { sebelumnya serta mengajukan pertanyaan untuk mengingat dan menghubungkan dengan materi } \\
\text { selanjutnya. }\end{array}$} \\
\hline \multirow{2}{*}{\multicolumn{2}{|c|}{$\begin{array}{l}\text { Menyampaikan motivasi tentang tujuan dan manfaat dengan mempelajari materi : Teks Prosedur } \\
\text { Menjelaskan hal-hal yang akan dipelajari, kompetensi yang akan dicapai, serta metode belajar } \\
\text { yang akan ditempuh. }\end{array}$}} \\
\hline & \\
\hline Sintaks & Kegiatan Inti (50 menit) \\
\hline $\begin{array}{l}\text { 1. Memonitor } \\
\text { keaktifan dan } \\
\text { perkembangan } \\
\text { proyek }\end{array}$ & $\begin{array}{l}\text { Guru meminta siswa untuk menunjukkan hasil kerja proyek membuat } \\
\text { teks prosedur di Google Classroom pada fitur tugas. Selanjutnya guru } \\
\text { memberi komentar, arahan, dan bimbingan dalam proyek pembuatan } \\
\text { teks prosedur yang telah dibuat oleh siswa. }\end{array}$ \\
\hline 2. Menguji hasil & $\begin{array}{l}\text { Siswa memperbaiki hasil proyek yang sudah dibuat setelah mendapat } \\
\text { komentar, arahan dan bimbingan dari guru. }\end{array}$ \\
\hline $\begin{array}{l}\text { 3. Evaluasi } \\
\text { pengalaman } \\
\text { belajar }\end{array}$ & $\begin{array}{l}\text { Siswa megupload kembali hasil perbaikan tugas proyek menulis teks } \\
\text { prosedur untuk dinilai oleh guru. } \\
\text { Siswa menulis pengalaman belajarnya di kolom chat dan mengisi } \\
\text { angket yang diberikan guru. }\end{array}$ \\
\hline
\end{tabular}

\section{Kegiatan Penutup (15 menit)}

Siswa membuat rangkuman/simpulan pelajaran tentang poin-poin penting yang muncul dalam kegiatan pembelajaran yang baru dilakukan.

Guru mengingatkan kembali kepada siswa bahwa pada pertemuan yang akan datang siswa sudah siap menulis teks prosedur dengan benar.

\section{Hasil Evaluasi}

Penerapan Model Pembelajaran Project Based Learning di jenjang pendidikan SMA/SMK dipandang cukup berhasil seperti penelitian yang dikakukan oleh Lydiati, (2019), yang melaporkan bahwa Pembelajaran Project Based Learning dapat meningkatkan kreatifitas siswa dalam mempelajari Statistika.

Penelitian yang dilakukan Ermavianti (2020), menyebutkan bahwa Model Pembelajaran Project Based Learning cocok diterapkan di Masa Pandemi Covid 19. Dengan pemberian tugas proyek memungkinkan siswa mengoptimalkan potensi visual dan kinestetiknya untuk mengerjakan tugas proyek yang diberikan guru.

Berbekal dari hasil dua penelitian itu, penulis mencoba menerapkannya di jenjang SMP. Langkah yang dilakukan yaitu penulis mendesain penilaian tugas proyek menulis teks prosedur pada fitur tugas di Google classroom. Teknisnya penulis membuat tugas proyek lalu mengirim tugas proyek itu ke siswa melalui link. Siswa membuka link tersebut, dipelajari dan dikerjakan. Apabila siswa sudah selesai mengerjakan, maka siswa diminta untuk mengirim tugas proyek yang sudah selesai dikerjakan tersebut. Tugas proyek itu di kirim ke fitur tugas dan klik serahkan. Setelah siswa menyerahkan tugas proyeknya di Google Classroom nantinya guru akan mengomentari dan menilai hasil tugas proyek siswa.

Dalam praktiknya ada siswa yang membuat dalam kurun waktu satu hari selesai, ada yang dua hari atau tiga hari selesai. Namun ada juga yang harus diberitahu ulang oleh gurunya. Hal ini mengingat tentunya karena tugas yang dikerjakan siswa tidak hanya satu pelajaran tetapi banyak pelajaran. Kalau siswa memprioritaskan pelajaran Bahasa Inggris, maka dalam kurun waktu satu hari tugas itu selesai. Tetapi apabila siswa memprioritaskan mata pelajaran lain atau mengalami kesulitan mengerjakan tugas proyek, maka tugas proyek menulis teks prosedur bisa dua atau tiga hari baru selesai.

Keunggulan dari metode ini adalah penilaian dapat dilakukan secara paperless atau 
tanpa kertas. Nilai positif dari penilaian tanpa kertas (paperless assessment) adalah lebih praktis, siswa tidak perlu datang ke sekolah untuk mengumpulkan tugas proyek dan yang lebih penting tidak menimbulkan dan terjadi kerumunan.

Adapun kendalanya adalah ada sebagian siswa yang mengirim tugas melalui Google Classroom yang menfoto tugasnya dua halaman menjadi satu kali jepretan. Hal ini menyulitkan guru untuk membaca dan mengoreksi teks yang dibuat.

Disamping itu ada juga siswa yang tidak mengumpulkan lewat Google Classroom tetapi japri lewat WA. Sebagai solusinya guru menyarankan kepada siswa untuk meminta ajari temannya agar bisa mengirim melalui Google Classroom.

Ada juga siswa yang belum mengumpulkan sampai batas waktu yang ditentukan. Hasil keterangan dari wali kelas mereka di pelajaran lain ternyata juga kurang aktif.

Solusi untuk masalah ini adalah guru mengirimkan daftar siswa yang sudah mengumpulkan tugas proyek di grup WA Kelas IX F. Dalam WA tersebut guru juga menyuruh siswa yang belum mengumpulkan agar segera mengumpulkan. Guru memberi kebijakan dengan memberi tambahan batas waktu pengumpulan tugas proyek.

Guru melakukan penilaian tugas proyek siswa melalui fitur tugas di Google Classroom. Guru memberi komentar tentang hasil tugas siswa di kolom chat box. Kriteria yang digunakan untuk menilai hasil tugas proyek siswa dijelaskan pada tabel 3 berikut.

Tabel 3. Skor Penilaian Menulis Teks Prosedur

\begin{tabular}{clc}
\hline No. & \multicolumn{1}{c}{ Indikator } & Skor \\
\hline 1. & $\begin{array}{l}\text { Menulis judul dengan } \\
\text { benar }\end{array}$ & $1-20$ \\
2. & $\begin{array}{l}\text { Menulis ingredients atau } \\
\text { composition dengan benar }\end{array}$ & $1-20$ \\
3. & $\begin{array}{l}\text { Menulis langkah-langkah } \\
\text { dengan benar }\end{array}$ & $1-20$ \\
4. & $\begin{array}{l}\text { Mendesain tulisan dengan } \\
\text { baik dan menarik }\end{array}$ & $1-20$ \\
5. & $\begin{array}{l}\text { Mengumpulkan tugas } \\
\text { proyek tepat waktu }\end{array}$ & $1-20$ \\
\hline
\end{tabular}

Guru melakukan penilaian hasil tugas proyek siswa berdasarkan urut kirim tugas. Setelah semua siswa mengumpulkan tugas dan dilakukan penilaian. Hasil sebaran nilai untuk seluruh siswa terkait tugas proyek menulis teks prosedur dapat dilihat pada tabel 4 berikut.
Tabel 4. Hasil penilaian terkait menulis teks prosedur.

\begin{tabular}{cccc}
\hline $\begin{array}{c}\text { Rentang } \\
\text { Nilai }\end{array}$ & $\begin{array}{c}\text { Jumlah } \\
\text { Siswa }\end{array}$ & Persentase & Kriteria \\
\hline $90-100$ & 1 & $3,22 \%$ & Amat Baik \\
$80-89$ & 18 & $58,06 \%$ & Baik \\
$70-79$ & 12 & $38,70 \%$ & cukup
\end{tabular}

Dari tabel 4 di atas, dapat dijelaskan bahwa ada 3,22\% memperoleh nilai antara 91-100 dengan kriteria amat baik, dan ada 58,06\% memperoleh nilai antara 80-89 dengan kriteria baik, serta ada $38,70 \%$ memperoleh nilai antara 70-79 dengan kriteria cukup. Rata-rata nilai yang diperoleh siswa 80,84.

Dalam kegiatan penilaian ini semua siswa sudah mengumpulkan tugas. Walaupun ada dua siswa yang terkendala HP bermasalah yang tidak bisa mengirim melalui Google Classroom. Dengan demikian berarti penggunaan Google Classroom sebagai media pembelajaran dapat dipandang cukup efektif diterapkan dalam kegiatan pembelajaran jarak jauh. Hal ini dikarenakan sebagian besar siswa bisa menggunakan aplikasi Google Classroom ini dengan baik dan mudah.

\section{Simpulan dan Saran}

Sebagai simpulan dari artikel ini adalah bahwa model pembelajaran Project Based Learning melalui Google Classroom dapat diterapkan dalam kegiatan Pembelajaran Jarak Jauh (PJJ) di Kelas IX F SMP Negeri 2 Mirit.

Adapun sarannya adalah bahwa dalam Masa Pandemi Covid 19 guru dapat menerapkan model pembelajaran Project Based Learning melalui Google Classroom dalam kegiatan pembelajarannya. Lebih baik lagi apabila mendokumentasikannya dalam bentuk best practice sebagai bukti bahwa sebagai guru sudah melaksanakan Pengembangan Keprofesian Berkelanjutan Sub unsur Publikasi Ilmiah

\section{Daftar Pustaka}

Anderson, Mark and Kathy. (2003). Text Types in English, Malaysia: Macmillian Education Australia Pty Ltd.

Dinas Pendidikan Kabupaten Kebumen. (2020). Implementasi Kurikulum 2013 Masa Pandemi Covid 19, Kebumen: Dinas Pendidikan.

Ermavianti, Dwi. (2020). Optimalisasi Kemampuan Berfikir Kritis Siswa di Tengah Pandemi Covid 19 pada Pembelajaran Tata Rias. Ideguru: Jurnal Karya Ilmiah Guru, $5(1)$,

27-33. DOI: https://doi.org/10.51169/ideguru.v5 i1.142 
Harususilo, Y. E. (2020). 4 Kunci Pembelajaran di Rumah Bermakna dan Menyenangkan dari Sekolah Kharisma Bangsa. https://edukasi.kompas.com/read/2020/04 /14/182638771/4-kuncipembelajaran-dirumah-bermakna-dan-menyenangkan-darisekolah

Kementerian Pendidikan dan Kebudayaan. (2014). Panduan Penguatan Proses Pembelajaran Sekolah Menengah Pertama, Jakarta: Direktorat Pembinaan SMP.

Kementerian Pendidikan dan Kebudayaan Republik Indonesia. (2019). SE Mendikbud: Penyederhanaan Rencana Pelaksanaan Pembelajaran.

Kementerian Pendidikan dan Kebudayaan Republik Indonesia. (2020). SE Mendikbud: Pelaksanaan Kebijakan Pendidikan dalam Masa Darurat 12 Penyebaran Covid-19. https://setkab.go.id/mendikbud-terbitkansepelaksanaan-kebijakan-pendidikan-saatcovid-19/

Lydiati, Ida. (2019). Peningkatan Kreatifitas Peserta Didik pada Materi Statistika melalui Model Pembelajaran PjBL-STEM Kelas XII MIPA 6 SMA Negeri 7 Yogyakarta, Ideguru: Jurnal Karya Ilmiah Guru, DOI: https://doi.org/10.51169/ideguru.v4 i2.94

Marharjono. (2020). Benefits of Learning History Using Google Classroom at The Covid-19
Pandemic. Ideguru: Jurnal Karya Ilmiah Guru, 5(1), 56-63. https://doi.org/10.51169/ideguru.v5i1.15 5

Nurrohmah, (2021). Efektifitas Aplikasi ELearning Google Classroom Untuk Meningkatkan Kemampuan Ceramah Peserta Didik. Retrieved January 1st, 2021 from https://guruberbagi.kemdikbud.go.id/.

Rosidah, Ati, (2020), Pemanfaatan Google Classroom Untuk Pembelajaran Online, Jakarta: LPMP Jakarta.

Suyaman, Maman, (2020), Model-model Pembelajaran Sastra Berbasis Jejaring, Naskah Tidak Diterbitkan.

Susilohadi, Gunarso. (2008). Contextual Teaching and Learning Bahasa Inggris: Sekolah Menengah Pertama/Madrasah Tsanawiyah Kelas IX Edisi 4 Jakarta: Pusat Perbukuan, Departemen Pendidikan Nasional.

Wardiman, Artono. (2008). English in Focus for Grade IX Junior High School (SMP/MTs, Jakarta: Pusat Perbukuan Departemen Pendidikan Nasional.

Yuliana, Cecilia, M.M. (2020). Project Based Learning, Model Pembelajaran Bermakna Di Masa Pandemi Covid 19, Lampung: LPMP Lampung.

Zaida, Nur. (2011). Practice Your English Competence, Jakarta: Erlangga. 